\title{
THE EFFECT OF ETHICAL LEADERSHIP AND ORGANIZATIONAL CULTURE ON WORK ETHOS AND ITS IMPACT ON ORGANIZATIONAL PERFORMANCE: A CASE STUDY IN REGENCY DEPARTMENT OF LANDS OF LOMBOK ISLAND, INDONESIA
}

\author{
Susmianto*, Hermanto, Siti Nurmayanti \\ University of Mataram, Indonesia \\ *E-mail: ruka.anto@gmail.com
}

\begin{abstract}
A leader should be concerned about the influence of his leadership on working culture and environment of the employees. These responsibilities include the ethical responsibility of treating employees with mutual respect, service, fairness, and honesty. This study aimed to determine the influence of ethical leadership and organizational culture on the work ethos and its impact on the performance of the organization on the Department of Lands. A quantitative research method was applied in this study. The sample of research are 69 respondents with cluster sampling method. The research was conducted at National Department of Lands in Lombok Island. The data analysis technique used is SEM using SmartPLS 3.0 program. The results showed that ethical leadership has no significant effect on work ethos, while organizational culture has a significant effect on work ethos. Furthermore, both work ethos and ethical leadership had a significant effect on organizational performance, organizational culture has a significant effect on organizational performance.
\end{abstract}

\section{KEY WORDS}

Ethical leadership, organizational culture, work ethos, organizational performance, lands.

The public demand for the improvement of the performance of the national bureaucracy has become a common agenda at the moment. The level of public confidence in government organizations in terms of public service delivery has had a significant impact on the process of service delivery itself. The GDS 2002 (Governance and Decentralization) survey in 20 Indonesian Provinces conducted by Dwiyanto (2006) shows the results of government organizations in administering public services, the time required to complete a service is often not clearly regulated. Public service office unlikely to estimate the required time complete a service. It is explained that because of the reluctance to determine clearly the time required to complete a task, the public service providers' act arbitrarily when serving the community. As a result, service time uncertainty tends to occur almost in all types of public services. In addition, according to the Financial and Development Supervisory Agency quoted by Bastaman (2010), a disappointment of the society over the administration of the government is induced by dissatisfaction with the accountability of state organizers for the trust given to them.

According to Slamet (2009) performance management system is a process used to identify, encourage, measure, evaluate, improve and reward the worker's performance. Organizations require continuous improvement in performance in order to survive and well developed, moreover human resources are a major asset for transformation and innovation in organizations (Asgharpoor, 2006 in Kelidbari et al., 2016). Success or failure of performance achieved by an organization, influenced by the level of staff performance, both individually and in groups. Organizational performance, in this case, public organization, becomes an important role as a benchmark of the success of a government organization in providing services to the citizens. In order to achieve that success, organizational performance is mainly influenced by various factors including ethical leadership, organizational culture, and work ethos. In the aspect of leadership, motivation is one of fundamental value so those affect members of the organization in the aspects of attitudes, behaviors, perceptions, and values associated with the work ethos and organizational 
culture. Leadership is one of the determinants of organizational success. Leadership shifts from time to time and is contextually based on the social, political and cultural developments prevailing in its era. None of the best leadership styles are universally applicable to all situations and environments.

According to Sutrisno (2009), the role of leaders in an organization is very crucial because it is leaders who will move and direct the organization in an effort to achieve organizational goals. In managing their authority, leaders are expected to make changes in others because of their power and control towards the staff. The leader also should have more concern to the influence of his leadership on the working culture of the staff. These responsibilities include the ethical responsibility of treating employees with mutual respect, service, fairness, and honesty (Northouse, 2013). Based on data from the National Land Agency (abbreviated: BPN) shows the high performance of the Department of Lands in Lombok Island, West Nusa Tenggara Province which is $94 \%$ of the settlement of task. However, the realization of job completion based on the target is not enough because there are still many public complaints regarding the quality of services such as the length of the certification process time, the high cost, and the absence of transparency in cost and time.

As explained above, this study evaluates some previous research results as well as explore some novelty. First, assessing the ethical leadership variables and organizational culture on work ethos and its impact on organizational performance. This is because previous studies have shown the different results. Second, one of the variables used in this study is ethical leadership, where the use of ethical leadership variables in some previous studies is still limited. Third, some previous studies have shown that ethical leadership, organizational culture, and work ethos have a direct impact on performance, while a number of research results prove that ethical leadership, organizational culture has no direct impact on performance but through mediation or moderation variables, such as job satisfaction (Karnama \& Tafreshi, 2015), employee productivity (Azwan et al., 2015), self-efficacy and organizational identity (Kelidbari et al., 2016). The research that will be conducted aims to observe the influence of ethical leadership and organizational culture on performance through work ethos. Therefore, the purpose of this research is to comprehend the impact of ethical leadership and organizational culture on performance through work ethos at Department of Lands in Lombok Island, West Nusa Tenggara.

\section{LITERATURE REVIEW}

Ethical Leadership. Ethical leadership is the process of influencing employees through the broader values, principles, and beliefs of the constraints of accepted norms in organizational behavior (Buble, 2012). In relational concepts, this ethical leadership is built in and through social interaction with staff. Indicators of ethical leadership by Northouse (2013) including mutual respects, serving others, objectivity, honesty, and establish the community.

According to Gomez, Balkin and Cardy cited in Alshammari et al. (2015) argue that the distinctive pattern of ethical leadership is to embody and articulate organizational goals and values. Leaders in this context symbolize morals and narrate ethics to show the practical basis of ethical values. The ethical leader should be a role model for the ethical manner of business in society by putting aside unethical behavior for personal satisfaction and taking full responsibility for improper decisions that can affect the organization. Leadership ethics shows a normative response to personal action as well as interpersonal relationships within the organization. The role of ethical leadership in influencing performance roots into motivating, inspiring and considerate.

Ethical leadership will affect employees with values, principles, and beliefs. With its authority, leaders will always be honest, work with their employees, and assist in resolving conflicts by implementing changes relating to the value of workers and the value of organizations and communities in the workplace (Heifetz in Northouse, 2013). Furthermore, ethical leaders can be regarded as people who have strong moral, good character, trustworthy and caring for others (Trevino \& Brown, 2004). 
Aslan and Sendogdu (2012), in his research, found that ethical leadership has a positive and significant relationship with ethical values in the company and individual behavior that indicate the work ethos. The leaders of the Department of Lands in Lombok Island of West Nusa Tenggara Province are trying to build communication with subordinates while motivating their subordinates to uphold the value of honesty, obeying laws and legal policies, respecting others and being responsible for the work. These efforts were conducted to establish positive working behaviors and a great commitment to improving the performance. Here is the hypothesis formulation:

$\mathrm{H}_{1}$ : Ethical leadership has a significant effect on work ethos.

Organizational Culture. Organizational culture as a beliefs and expectations shared by members of the organization (Schwartz \& Davis cited in Wirawan, 2007). Such beliefs and expectations produce strong values that shape the behavior of individual and group members of the organization. Organizational culture tends to be a set of assumptions that direct interpretation and action within the organization with appropriate behavioral depictions for different positions (Ravasi \& Schultz, 2006). Organizational culture includes involvement, consistency, adaptability, and mission (Denison, 2000).

In practice organizational culture has several types and types (Quinn \& McGrath cited in Uha, 2013), namely:

a. Rational culture is the process of individual information (clarification of the objectives of logic considerations, guidance devices) is assumed as tools for the performance objectives shown (efficient, productivity, and profit or impact).

b. The ideological culture of intuitive information processes (from deep knowledge, opinion, and innovation) is assumed as a means of revitalization (outside support, resource support, and growth).

c. The consensus culture of collective information processes (discussion, participation, and consensus) is assumed as a means of cohesion (climate, morale, and teamwork).

d. A hierarchical culture of formal information processes (documents, compilations, and evaluations) is assumed as a means for sustainability goals (stability, control, and coordination).

Based on research conducted by Semedi (2009), it was found that there is a strong correlation between organizational culture and work ethos, which shows the stronger the organizational culture the higher the application of professional work ethos. At the place of study, the achievement of task completion and service target is closely related to the work ethic of its employees to work better in achieving organizational goals. Hence can be formulated hypothesis:

$\mathrm{H}_{2}$ : Organizational culture has a significant effect on work ethos.

Work Ethos. Sinamo (2005) states that work ethos is a set of positive work behaviors rooted in eternal consciousness, fundamental beliefs, accompanied by a total commitment to an integral work paradigm. Indicators of work ethos proposed by Sinamo (2005) include: work is mercy, work is trust, work is a call, work is actualization, work is worship, work is art, work is an honor, work is service. The study by Nizam et al. (2016) states that there is a significant relationship between work ethic and work performance. Work ethos proved to be one of the factors of a good employee performance predictor. This validates that the work ethos will result in high staff performance and demonstrate that the application of work ethos can help the organization achieve overall good performance. Some employees at the Department of Land in Lombok Island, West Nusa Tenggara Province often work exceed the working hours to complete their tasks related to land services, although they are not rewarded for the excess hours.

$\mathrm{H}_{3}$ : Work ethos has a significant effect on organizational performance.

Performance. Mahsun (2006), explained that performance is a description of the implementation of an activity/ program/policy in order to achieve the goals, objectives, mission, and vision of the organization contained in strategic planning of an organization. According to Mahsun (2006), government performance indicators include input indicators, processes, outputs, outcomes, benefits and impacts. 
Several studies have been conducted on the role of ethical leaders in achieving performance improvement. The study conducted by Toor \& Ofori (2009) states that ethical leadership mediates roles in the relationship between organizational culture and performance. The ethical leader will create a comfortable, effective working environment, and crucially lead to improved organizational performance. In addition, ethical leadership has a positive effect on employee performance (Resick et al., 2006). Here is the fourth hypothesis:

$\mathrm{H}_{4}$ : Ethical leadership has a significant effect on organizational performance.

In research conducted Shahzad et al., (2012) states that organizational culture has a positive impact on employee performance. Research shows that every individual in the organization has a different culture and first tries to adjust to the norms and values of the organization. Application of culture organizations is helping employees to do their work efficiently and effectively. The cultural form that is implemented in the research place is a sense of togetherness and the desire to provide satisfaction for the services provided to the community, encouraging employees to work better again leading to higher organizational performance.

$\mathrm{H}_{5}$ : Organization culture has a significant effect on organizational performance.

\section{METHODS OF RESEARCH}

This research is quantitative research. Based on the level of explanation, this study includes the type of associative research that investigates the correlation between two or more variables (Sugiyono, 2014). This research was conducted at Department of Lands in Lombok Island with 69 respondents. The variables found in this study are ethical leadership variables measured by using indicators developed by Northouse (2013), organizational culture variables are measured using indicators developed by Wirawan (2007), work ethic variables are measured using indicators developed by Sinamo (2005), and organizational performance variables were measured using indicators developed by Dwiyanto (2012).

Weights on each variable using a five-level scale (Likert scale) consisting of strongly agree, agree, simply, disagree, and strongly disagree. The result of validity test of research instrument by using correlation technique of Product Moment Pearson shows that the correlation coefficient value for each item statement is greater than $0.3(r>0.3)$ so it is included the valid category. Similarly, the instrument reliability test results show that all items in the research variables are reliable because Cronbach's Alpha is above 0.6. Data analysis in this research using Partial Least Square (PLS).

\section{RESULTS AND DISCUSSION}

In accordance with the hypothesis that has been formulated, then in this study analysis of inferential statistical data measured by using software SmartPLS 3.0.

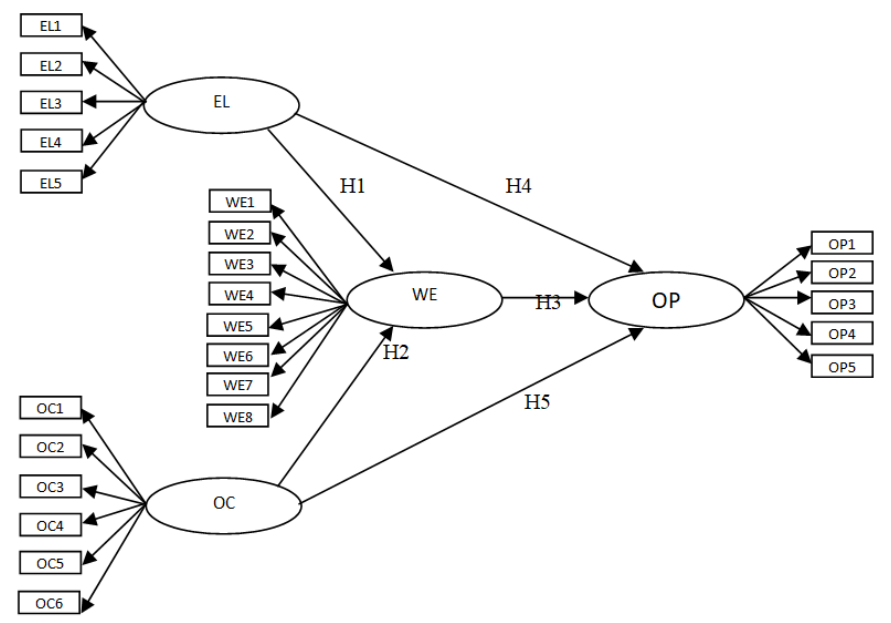

Figure 1 - Hypothesis model 
Based on model measurement (outermodel) that is test of discriminant validity and composite reliability $(C R)$ show all variable is valid (value $\sqrt{ } A V E>0,5)$ and reliable (value of $\mathrm{CR}>0,7)$.

Table 1 - Value of Average Variace Extract (AVE) and Composite Reliability (CR) Latent Variable Research

\begin{tabular}{|c|c|c|c|}
\hline Variables & $\sqrt{ }$ AVE & CR & Information \\
\hline Ethical Leadership (EL) & 0,838 & 0,921 & Valid \& Reliable \\
\hline Organizational Culture (OC) & 0,788 & 0,907 & Valid \& Reliable \\
\hline Work Ethos (WE) & 0,780 & 0,926 & Valid \& Reliable \\
\hline Organizational Performance (OP) & 0,758 & 0,870 & Valid \& Reliable \\
\hline
\end{tabular}

Source: Data that have been processed by using SmartPLS 3.0

Measurement of structural model (inner model) is used to know the relationship between construct, significance value and R-Square research model.

Table 2 - R-square value of dependent construct

\begin{tabular}{|c|c|}
\hline Variable & R-Square \\
\hline Work Ethos & 0,203 \\
\hline Organizational Performance & 0,523 \\
\hline
\end{tabular}

Source: Data that have been processed by using SmartPLS 3.0

Table 2 shows that the value of R-square for construct work ethos is 0.203 , which means that ethical leadership and organizational culture variables influence work ethos by $20.3 \%$, while $79.7 \%$ is influenced by other un-researched variables. The value of R-square for the construct of organizational performance is 0.523 which means that ethical leadership variable, organizational culture and work ethos influence organizational performance of $52.3 \%$.

Hypothesis testing was done to find out whether the proposed hypothesis is rejected or accepted by comparing the t-statistic value generated from the bootstrapping process in the PLS with the t-table value. If t-statistic value is higher than t-table (1.96) with the significance of the $5 \%$ level (one tailed), the hypothesis is accepted, but if t-statistic value is lower, the hypothesis is rejected.

Table 3 - Hypothesis Testing Result

\begin{tabular}{lcccc}
\hline \multicolumn{1}{c}{ Relationship between Variables } & Path Coefficient & T-statistics & $P$ value & Conclusion \\
\hline Ethical Leadership $\rightarrow$ Work Ethos & 0,233 & 1,558 & 0,120 & rejected \\
\hline Organizational Culture $\rightarrow$ Work Ethos & 0,321 & 2,381 & 0,018 & accepted \\
\hline Work Ethos $\rightarrow$ Organizational Performance & 0,406 & 4,227 & 0,000 & accepted \\
\hline Ethical Leadership $\rightarrow$ Organizational Performance & 0,326 & 3,195 & 0,001 & accepted \\
\hline Organizational Culture $\rightarrow$ Organizational Performance & 0,215 & 2,611 & 0,005 & accepted \\
\hline
\end{tabular}

Source: Data that have been processed by using SmartPLS 3.0

Based on Table 3, the effect of ethical leadership on work ethos with coefficient $=$ 0,233 and $p$-value $=0,120$, it means that ethical leadership has no significant effect on work ethos. Thus hypothesis 1 is rejected. This shows that ethical leadership has no significant effect on improving work ethos of employees. The ethical leaders in the Land Office not have a significant effect on the improvement of the work ethos of employees, or it can be said that the strong work ethos of employees in the Land Office is not caused by the attitude and behavior of the existing leadership in there, but caused by other factors such as religious (spirituality), cultural, socio-political factors, geographical environment, education, economic structure, individual intrinsic motivation. This study is in line with research conducted by Gustinsia et al., (2012). But this research different with research of Aslan \& Sendogdu (2012) which states that ethical leadership has a significant effect on the work ethos. 
The effect of organizational culture on work ethos with coefficient $=0,321$ and $p$-value $=0,018$, it means that organizational culture have significant effect to work ethos. Thus hypothesis 2 is accepted. This shows that the stronger the organizational culture will be the higher the work ethos. Characteristics of organizational culture dimension that exist in Land Office in Lombok Island which have positive and significant impact to work ethos is achieved. It also shows that the stronger the organizational culture in the Land Office in Lombok Island so that the work ethos of employees becomes stronger as well. This research is in line with research conducted by Wirawan (2009), and Prasetyanto (2014).

The effect of work ethos on organizational performance with coefficient $=0,406$ and $p$ value $=0,000$, it means that work ethos have significant effect to organizational performance. Thus hypothesis 3 is accepted. This shows the stronger work ethos of employees, the higher the organizational performance. The human resources (HR) in the Land Office is not proportional to the size of the annual target for the program / activity of land services on the Lombok island, but the lack of existing human resources still managed to improve the productivity of the Land Office in providing services to the community. The high productivity can be realized with the employees who are ready to work wholeheartedly, responsible, creative and have a strong work ethos. This study is in line with research conducted by Sugiyanto and Sutanto (2010), Nasution (2016), and Salahudin et al., (2016).

The effect of ethical leadership on organizational performance with coefficient $=0.326$ and $p$-value $=0.001$, meaning that ethical leadership has significant effect on organizational performance. Thus hypothesis 4 is accepted. This shows that the more ethical a leader in an organization, the higher the performance of the organization. Result of analysis test supported by descriptive data of result of research indicate that most of the leadership in Regency / City Land Service Office in Lombok Island have ethics shown by attitude of respecting and appreciating employees, caring and objective in giving opportunity to employees to move forward and developed, be honest and consider employees. In detail the success of leadership in showing ethical behavior is so successful in improving organizational performance. This study is in line with research conducted by Bello (2012), Sabir et al., (2012), Cheraghi et al. (2015), Karnama \& Tafresi (2015), and Alshammari et al. (2016).

The effect of organizational culture on organizational performance with coefficient $=$ 0,215 and $p$-value $=0,005$, meaning that organizational culture has significant effect on organizational performance. Thus hypothesis 5 is accepted. This shows that the stronger the organizational culture the higher the organization's performance. The results of the analysis test supported by the descriptive data of the research results indicate that the employees of the Regency / City Land Office in Lombok Island have a strong organizational culture, where the organizational culture has increased the intimacy and togetherness of the Land Office employees to improve productivity through the achievement of physical realization and budget by optimizing the source power that exists in the implementation of programs / activities. In addition, the intimacy and togetherness is also evident from the efforts of employees in improving the quality of service, responsiveness, responsibilitas and accountability in accordance with community expectations. The results of this study are in line with research by Nga'ang'a and Nyongesa (2012), Shahzad et al. (2012), Ahmed and Shafiq (2014), and Nikpour (2017).

\section{CONCLUSION}

The influence of ethical leadership on the Land Office on Lombok Island is not very influence in improving work ethos of employees. The strong work ethos of employees is caused by the existing organizational culture, but the leaders need to consider other aspects that can enhance work ethos such as to organizing religious activities in the form of training or lectures. Religious activities are conducted to provide an understanding to employees about the importance of being honest, responsible, loyal, and able to refrain from corruption, collusion and nepotism (abbreviated: KKN). 
Organizational performance is included in the high category. The high organizational performance is caused by the success of the leader in showing the mutual respect, honest, fair, willingness to serve and their success in building togetherness with the employees to realize the priority programs. In addition to leadership, organizational culture is also an important factor that encourages the high organizational performance of Land Office in Lombok Island, the employees understand the vision and mission of the organization that is implemented in the annual programs.

\section{REFERENCES}

1. Ahmed, M., \& Shafiq, S. (2014). The impact of organizational culture on organizational performance: A case study of telecom sector. Global Journal of Management \& Business Research, 14(3), 21-30.

2. Alshammari, A., Almutairi, N. N., \& Thuwaini, S. F. (2015). Ethical leadership: The effect on employees. International Journal of Business and Management, 10(3), 108-116.

3. Aslan, S., \& Sendogdu, A. (2012). The mediating role of corporate social responsibility in ethical leader's effect on corporate ethical values and behavior. Procedia - Social and Behavioral Sciences, 58, $693-702$.

4. Azwan, Chan. S., \& Majid, M.S.A. (2015). Pengaruh Budaya organisasi, komitmen organisasi dan motivasi kerja terhadap produktivitas pegawai serta dampaknya pada kinerja badan investasi dan promosi Aceh. Jurnal Manajemen Pascasarjana Universitas Syiah Kuala, v 4 (1), 241-249.

5. Bastaman, K. (2010). Pengaruh iklim dan kepuasan komunikasi serta komitmen terhadap kinerja pegawai. Jurnal Mimbar LPPM Unisba, 16 (2), 135-146.

6. Bello, S.M. (2012). Impact of ethical leadership on employee job performance. International Journal of Business and Social Science, 3(11), 228-236.

7. Buble, M. (2012). Interdependence of organizational culture and leadership styles in large Firms. management: Journal of Contemporary Management Issues, 17(2), 85-97.

8. Chehraghi, N.D., Moghadam, Y.M. \& Kasmaie, A.D. (2015). The effect of ethical leadership on employee voice and silence between them in Mega Motor Company. Europan Journal of Natural and Social Sciences, 4(1), 1854-1865.

9. Denison, D. R. (2000). Organizational culture: Can it be a key lever for driving organizational change. In S. Cartwright, \& C. Cooper (Eds.), the handbook of organizational culture. London: John Wiley \& Sons.

10. Dwiyanto, A. (2006). Reformasi Birokrasi Publik di Indonesia. Cetakan Pertama. Yogyakarta: Galang Printika.

11. Gustinsia, V., Nurazi, R. \& Bachri, S. (2012). Pengaruh kepemimpinan, lingkungan kerja dan disiplin kerja terhadap etos kerja karyawan pada Bank Bengkulu Capem Wilayah Curup. Jurnal IImiah Manajemen, 13 (2), 123-137.

12. Karnama, A.K. \& Tafreshi, S.M. (2015). Analyzing the effect of moral leadership on organizational performance through the mediation of employees job satisfaction in communication and technologies unite of army. Indian Journal of Fundamental and Applied Life Sciences 5(81), 4749-4761.

13. Kelidbari, H.R.R., Adei, M. \& Ebrahaimi, P. (2016). The role of ethical leadership on employee performance in Guilan University of Medical Sciences. Procedia-Social and Behavioral Sciences, 230, 463-470.

14. Mahsun, M. (2006). Pengukuran Kinerja Sektor Publik. Yogyakarta: Fakultas Ekonomi UGM.

15. Nasution, A.P., Mahargiono, P.B. \& Soesatyo, Y. (2016). Effect of leader styles, organizational climat and ethos of work on employee produtivity (PT. HP Metals Indoesia The Powder Coating). International Journal os Business and Management, 11(2), 262 273.

16. Ng'ang'a, M. J., \& Nyongesa, W. J. (2012). The impact of organizational culture on performance of educational institutions. International Journal of Business \& Social Science, 3(8), 211-217. 
17. Nikpour, A. (2017). The impact of organizational culture on organizational performance: The mediating role of employee's organizational commitment. International Journal of Organizational Leadership, 6, 65-72.

18. Nizam bin Salahudin, S., Nur Ruzainy bin Alwi, M., Sarah binti Baharuddin, S., \& Syafina binti Halimat, S. (2016). The Relationship between Work Ethics and Job Performance. The Eruopean Proceedings of Social \& Behavioural Science, 3, 465-471. http://doi.org/10.15405/epsbs.2016.11.02.43

19. Northouse, P.G. (2013). Kepemimpinan. Jakarta: PT. Indeks.

20. Prasetyanto, W.E. (2014). Analisis pengaruh gaya kepemimpinan, budaya organisasi, kepuasan kerja dan motivasi terhadap etos kerja guru pegawai negeri sipil di Daerah Istimewa Yogyakarta. Jurnal Bisnis Manajemen dan Akuntansi, 2(2), 30-40.

21. Ravasi, D., \& Schultz, M. (2006). Responding to organizational identity threats: Exploring the role of organizational culture. Academy of Management Journal, 49(3), 433-458.

22. Resick, C.J., Hanges,P.J., Dickson, M.W. \& Mitchelson, J.K. (2006). A Cross-Cultural Examination of the Endorsement of Ethical Leadership. Journal of Business Ethics, 63 (4), 345-359

23. Sabir, M.S., Iqbal, J.J., Rehman, K.U., Shah, K.A. \& Yameen, M. (2012). Impact of corporate ethical vaulues on ethical leadership and employee performance. International Journal of Business and Social Science, 3(2), 163-171.

24. Semedi, N.S. (2009). Pengaruh Budaya Perusahaan terhadap Etos Kerja Profesional Serta Kaitannya Dengan Peningkatan Kinerja Perusahaan Jasa Konsultan. PT. PPA Consutants, 1-16.

25. Shahzad, F., Luqman, R. A., Khan, A. R., \& Shabbir, A. L. (2012). Impact of organizational culture on organizational performance: An overview. Interdisciplinary Journal of Contemporary Research in Business, 3(9), 975-985.

26. Sinamo, J. (2005). Delapan Etos Kerja Profesional; Navigator Anda Menuju Sukses. Bogor: Grafika Mardi Yuana.

27. Slamet, A. (2009). Manajemen Sumber Daya Manusia. Semarang: Universitas Negeri Semarang Press.

28. Sugiyanto \& Sutanto, H. (2010). Membangun etos kerja yang proaktif guna mengoptimalkan kinerja melalui spiritual centered leadership, employee empowerment, organizational citizenship behavior. Buletin Ekonomi , 8(2), 70-170.

29. Sugiyono. (2014). Metode Penelitian Kuantitatif Kualitatif dan R\&D. Bandung : Alfabeta.

30. Sutrisno, E. (2009) Manajemen Sumber Daya Manusia. Edisi Pertama edition, Jakarta: Kencana Prenadamedia Grup.

31. Toor S. \& Ofori G. (2009). Ethical Leadership: Examining the Relationships with Full Range Leadership Model, Employee Outcomes, and Organizational Culture. Journal of Business Ethics, 90, 533-547.

32. Trevino, L.K., \& Brown, M.E. (2004). Managing to be Ethical: Debunking five Business Ethics Myths. Academy of Management Executive, 18 (2), 69-81

33. Uha, I.N. (2013). Budaya Organisasi Kepemimpinan dan Kinerja. Jakarta: Prenadamedia Group.

34. Wirawan. (2007). Budaya dan Iklim Organisasi Teori Aplikasi dan Penelitian. Jakarta: Salemba Empat. 